\title{
Relationships between sedimentary organics and benthic meiofauna on the continental shelf and the upper slope of the Gulf of Lions (NW Mediterranean)
}

\author{
A. Grémare*, L. Medernach, F. deBovée, J. M. Amouroux, G. Vétion, P. Albert \\ Observatoire Océanologique de Banyuls, Université Pierre et Marie Curie, Laboratoire d'Océanologie Biologique, \\ UMR CNRS 7621, BP 44, 66651 Banyuls-sur-Mer, France
}

\begin{abstract}
The relationships between the biochemical characteristics of sedimentary organics and benthic meiofauna in the Gulf of Lions were assessed based on samples collected at 19 sites during June 1998. We measured sediment granulometry, organic matter, organic carbon, nitrogen, carbohydrate, lipid, total hydrolyzable amino acid (THAA) and enzymatically hydrolyzable amino acid (EHAA) concentrations together with $\mathrm{C} / \mathrm{N}$ and EHAA/THAA ratios. Meiofauna abundance and nematode biomass were also analyzed. All biochemical parameters showed the same pattern of change relative to depth, with a decrease between 0 and $175 \mathrm{~m}$, a subsequent increase between 175 and $900 \mathrm{~m}$ and a final decrease at greater depths. This pattern was linked to sediment granulometry and more specifically to the occurrence of coarser sediments near the edge of the continental shelf. In contrast, meiofauna abundance and nematode biomass constantly decreased with depth. This suggests that organic matter availability does not control the quantitative characteristics of benthic meiofauna over the whole range of sampled depths. The relationships between biochemical descriptors of sedimentary organics and quantitative characteristics of benthic meiofauna were assessed in the 0 to $175 \mathrm{~m}$ depth range. Lipids and to a lesser extent EHAA correlated better with meiofauna abundance and nematode biomass than nitrogen, carbohydrates and organic contents. These results are discussed in view of the identification of biochemical descriptors of the nutritive value of sedimentary particulate organic matter.
\end{abstract}

KEY WORDS: Particulate organic matter $\cdot$ Meiofauna $\cdot$ Gulf of Lions $\cdot$ Continental shelf $\cdot$ Continental slope

Resale or republication not permitted without written consent of the publisher

\section{INTRODUCTION}

Particulate organic matter (POM), which is produced in the euphotic zone and then sinks down to the seafloor, constitutes a link between pelagic and benthic ecosystems (Graf 1992). During the last 2 decades the occurrence and importance of such a coupling has been increasingly documented through the analysis of the effects of changes in particle fluxes on the structure and functioning of benthic ecosystems. The effect of increasing particle fluxes on the abundance and the

*E-mail: gremare@obs-banyuls.fr biomass has been documented for various compartments of the benthic fauna (including microbes, meioand macrofauna) based on either spatial (Relexans et al. 1996, Smith et al. 1997) or temporal surveys (Grémare et al. 1997). Benthic respiration has also been shown to be positively correlated with the overlying primary production (Hargrave 1973) and to respond to changes in particle fluxes (Graf et al. 1983). Moreover, the study of life cycles in selected deep sea organisms has revealed the existence of a quick response to the sedimentation of different types of POM originating from overlying waters (Bishop \& Shalla 1994, Tyler et al. 1994). Both direct observations and biochemical assays carried out on deep sea sediments have docu- 
mented the quick arrival of fresh phytodetritus at the bottom-sediment interface at depths sometimes even exceeding $5000 \mathrm{~m}$ (Hecker 1990, Smith et al. 1996). The occurrence of quick sedimentation processes, allowing for the presence of fresh material at the watersediment interface, raises the issue of the assessment of POM nutritional value.

A proportion of the sedimentary POM corresponds to refractory forms that cannot be absorbed by benthic organisms because of the characteristics of their digestive systems (Plante \& Jumars 1992, Plante \& Shriver 1998). It thus seems essential to assess the particular fraction of POM that is available to benthic fauna to describe the interactions between these 2 compartments. A possible approach consists in mimicking digestion using enzymatic hydrolysis (Mayer et al. 1986, 1995, Lan \& Pan 1993, Dell'Anno et al. 2000). Based on the comparison between the biochemical composition of benthic primary consumers and their primary food sources, Phillips (1984) suggested that benthic detritivores may be limited by the availability of specific micronutrients (such as essential amino and fatty acids) rather than by bulk nutrients (such as carbon and nitrogen). This hypothesis was later supported by the analysis of population dynamics of opportunistic surface deposit feeders in the Chesapeake Bay (Marsh \& Tenore 1990). A sound biochemical approach aimed at assessing the nutritional value of POM must thus account both for its digestibility and for its capacity to meet the nutritional requirements of benthic fauna. One possible method is the biomimetic approach proposed by Mayer et al. (1995) for the quantification of enzymatically hydrolyzable amino acids in marine sediments.

Although this method is being increasingly utilized, its validity as a surrogate for determining the amount of proteins actually available to benthic primary consumers remains questionable due to the scarceness of studies coupling biochemical and bio-assays (Taghon \& Greene 1990, Charles et al. 1995, Grémare et al. 1997). A complementary approach consists of correlating the abundance or the biomass of benthic fauna with the biochemical characteristics of sedimentary organics (Soltwedel \& Thiel 1995, Relexans et al. 1996). Studies of this kind have mainly focussed on microand meiofauna, which are thought to quickly respond to POM inputs due to their small size and fast potential renewal rates, and become rapidly dominant as depth increases (Flach et al. 1999). As far as we know, none of these studies have yet employed a biomimetic approach.

The aim of the present paper was to compare the ability of a broad set of biochemical characteristics of sedimentary organics to describe quantitative changes in both the abundance and the biomass of benthic meiofauna. More specifically, our working hypothesis was that biochemical parameters resulting from a biomimetic approach should better correlate with quantitative characteristics of meiofauna than global descriptors of sedimentary organics (e.g. organic carbon, nitrogen). This question was assessed based on a field survey involving 19 stations located throughout the Gulf of Lions.

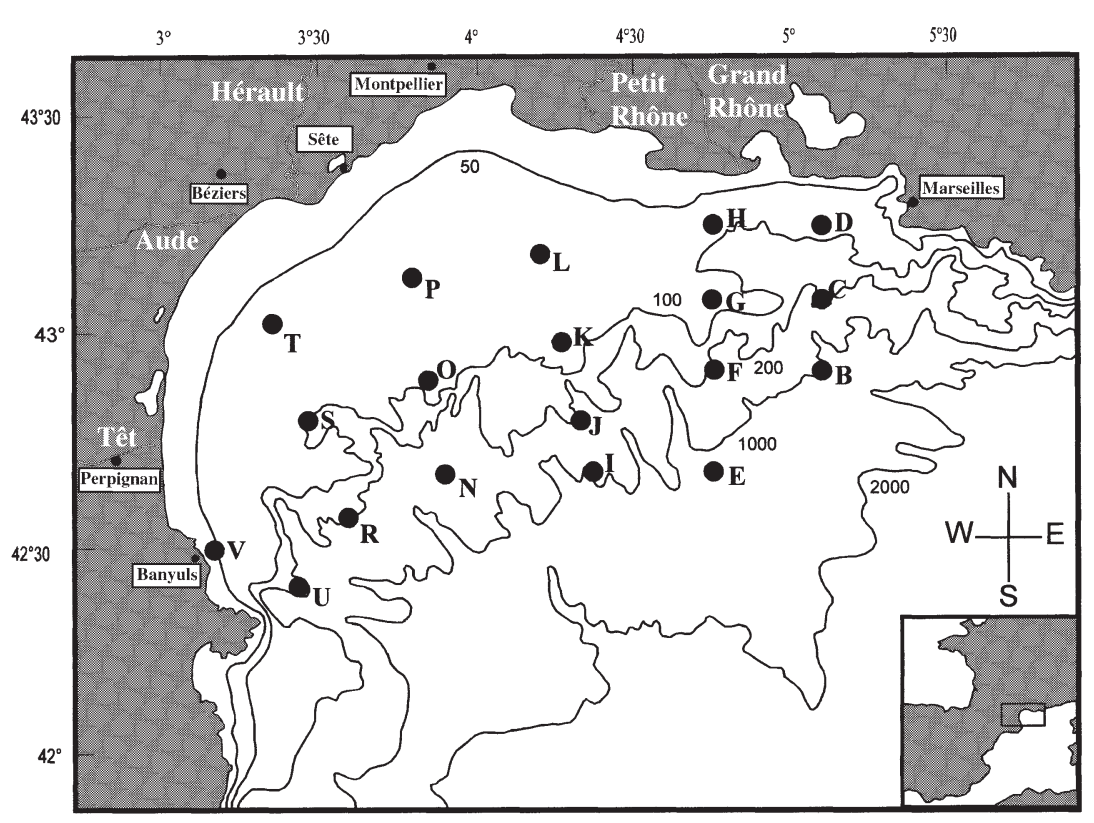

Fig. 1. Location of the 19 stations sampled during the Moogli II cruise

\section{MATERIALS AND METHODS}

Samples collection. A total of 19 stations were sampled during the Moogli II cruise, which took place on board the RV 'Suroît' between 2 and 28 June 1998 (Fig. 1). The geographic coordinates of these stations are provided in Table 1, together with their depth, distance to the coast and sampling date. Among the 7 stations deeper than $200 \mathrm{~m}, 3$ (B, F and U) were located within submarine canyons, and 3 (I, J and N), on the open slope. The depths of Stns I and U were close enough to allow direct comparisons between these 2 stations. To a lesser extent, this was also true for Stns J, N and F. Stn E was $1380 \mathrm{~m}$ deep and located at the mouth of the Petit Rhône canyon.

At each station, sediment cores $(9 \mathrm{~cm}$ in diameter) were taken using a 
Bowers \& Connolly midicorer (Ocean Scientific ${ }^{\circledR}$ ). This instrument is an impact corer designed to take 4 undisturbed cores at a time from the sea-bed. The centers of these cores are on a $300 \mathrm{~mm}$ square. The penetration rate in the sediment is about $50 \mathrm{~mm} \mathrm{~s}^{-1}$. There were 2 successful drops per station. The distance between these 2 drops was typically $<100 \mathrm{~m}$.

Biochemical assays. For assays 3 cores were randomly selected from the 2 drops and used for biochemical assays. The overlying water was immediately removed and the first centimeter of each core was cut, centrifuged (4500 rpm for $3 \mathrm{~min}$ ), briefly rinsed in distilled water, centrifuged again (4500 rpm, $3 \mathrm{~min}$ ), and then frozen $\left(-20^{\circ} \mathrm{C}\right)$. Back at the laboratory, sediment samples were freeze-dried, crushed, sieved on a $200 \mu \mathrm{m}$ mesh, and stored at $-20^{\circ} \mathrm{C}$ until analysis. All biochemical assays were run in triplicate for each of the 3 cores used for biochemical assays. They were carried out on the fraction $<200 \mu \mathrm{m}$ in size.

Organic contents were assessed by measuring the weight lost after combustion $\left(450^{\circ} \mathrm{C}\right.$ for $\left.5 \mathrm{~h}\right)$. Organic carbon and nitrogen contents were measured after acidification $(1 \mathrm{~N} \mathrm{HCl})$ using a CHN Perkin Elmer 2400 analyzer.

Carbohydrates were measured after Dubois et al. (1956). Briefly, $100 \mathrm{mg}$ DW of sediment was weighed and mixed with $6 \mathrm{ml}$ of distilled water. A $100 \mu \mathrm{l}$ subsample was taken, and $900 \mu \mathrm{l}$ of distilled water and $1 \mathrm{ml}$ of a $5 \%$ phenol solution was added. After vortexing, $5 \mathrm{ml}$ of pure sulfuric acid was added. Then, the tube was cooled at room temperature and centrifuged (2000 rpm, $5 \mathrm{~min}$ ). Optical density was read at $490 \mathrm{~nm}$ and converted in glucose equivalents.

Lipids were measured using the procedure of Barnes \& Blackstock (1973). Briefly, $100 \mathrm{mg}$ DW of sediment was weighed and mixed with $6 \mathrm{ml}$ of distilled water. A $500 \mu \mathrm{l}$ subsample was taken and dried at $90^{\circ} \mathrm{C}$ before $1.5 \mathrm{ml}$ of chloroform/methanol (2:1 v/v) was added. After 20 min of mixing, a $1 \mathrm{ml}$ subsample was collected and evaporated $\left(90^{\circ} \mathrm{C}\right)$. Then $500 \mu \mathrm{l}$ of pure sulfuric acid was added. After agitation and heating $\left(90^{\circ} \mathrm{C}\right.$, $10 \mathrm{~min}$ ), the tube was cooled in ice; $2.5 \mathrm{ml}$ of reactive ( $2 \mathrm{~g}$ of vanillin in $800 \mathrm{ml}$ of orthophosphoric acid and $200 \mathrm{ml}$ of distilled water) was added. After $30 \mathrm{~min}$ at room temperature, optical density was read at $520 \mathrm{~nm}$ and converted to lipid equivalents based on a cholesterol standard.

Total hydrolyzable amino acids (THAA) were acidified $\left(6 \mathrm{~N} \mathrm{HCl}, 100^{\circ} \mathrm{C}, 24 \mathrm{~h}\right)$, derivatised with orthophtaldialdehyde (OPA) and assayed using a Hitachi F4500 spectrofluorimeter. Fifteen mg DW of sediment was submitted to a strong acid hydrolysis $(500 \mu \mathrm{l}$ of $6 \mathrm{~N} \mathrm{HCl}, 100^{\circ} \mathrm{C}, 24 \mathrm{~h}$, under vacuum). Subsequently $0.1 \mathrm{ml}$ subsamples of the hydrolysates were neutralized with $0.1 \mathrm{ml}$ of $6 \mathrm{~N} \mathrm{NaOH}$ and buffered with $2 \mathrm{ml}$ of
$\mathrm{H}_{3} \mathrm{BO}_{3}(0.4 \mathrm{M}, \mathrm{pH}$ 10). These samples were let standing at room temperature for $1 \mathrm{~h}$ and then centrifuged (1000 rpm, $5 \mathrm{~min}$ ). One $\mathrm{ml}$ of phosphate buffer (pH 8) and $100 \mu \mathrm{l}$ of an OPA solution $(500 \mathrm{mg}$ in $5 \mathrm{ml}$ of methanol, $500 \mathrm{ml}$ OPA buffer [15 g boric acid, $0.5 \mathrm{~g}$ BRIJ 35 and $1.25 \mathrm{~g}$ of EDTA di-sodium salt, $\mathrm{pH} 9.8 \mathrm{]}$ and $0.25 \mathrm{ml}$ of $2 \beta$ mercaptoethanol) were added to $100 \mu \mathrm{l}$ of the buffered extract. THAA quantification was based on fluorescence measurements (excitation wavelength: $340 \mathrm{~nm}$; emission wavelength: $455 \mathrm{~nm}$ ) carried out exactly 4 min after the OPA addition. These measurements were converted into concentrations by comparison with a standard containing 17 amino acids (Sigma AA-S-18).

Enzymatically hydrolyzable amino acids (EHAA) were extracted following the procedure proposed by Mayer et al. (1995). They were quantified as described for THAA, $100 \mathrm{mg}$ DW of sediment was poisoned with $1 \mathrm{ml}$ of a solution containing 2 inhibitors of bacterial active-transport systems $(0.1 \mathrm{M}$ sodium arsenate and $0.1 \mathrm{mM}$ pentachlorophenol within a pH 8 sodium phosphate buffer). This mixture was allowed to incubate for $1 \mathrm{~h}$. A total of $100 \mu \mathrm{l}$ of proteinase $\mathrm{K}$ solution $\left(1 \mathrm{mg} \mathrm{ml}^{-1}\right)$ was then added, and the samples were incubated for $6 \mathrm{~h}$ at $37^{\circ} \mathrm{C}$. They were then centrifuged to discard remaining particulate material. Seventy-five $\mu l$ of pure TCA was added to $750 \mu \mathrm{l}$ of supernatant to precipitate macromolecules, which are considered to be nonsuitable for absorption by benthic invertebrates. Then $750 \mu \mathrm{l}$ of the supernatant was hydrolyzed $(750 \mu \mathrm{l}$ of $12 \mathrm{~N} \mathrm{HCl})$ and processed as described for THAA. In addition, a blank accounting for

Table 1. Sampling date, geographic coordinates, depth and distance to the coast of the 19 stations sampled during the Moogli II cruise

\begin{tabular}{|lcccrc|}
\hline Stn & $\begin{array}{c}\text { Date } \\
(\mathrm{d} / \mathrm{mo} / \mathrm{yr})\end{array}$ & $\begin{array}{c}\text { Latitude } \\
\mathrm{N}\end{array}$ & $\begin{array}{c}\text { Longitude } \\
\mathrm{E}\end{array}$ & $\begin{array}{c}\text { Depth } \\
(\mathrm{m})\end{array}$ & $\begin{array}{c}\text { Distance } \\
(\mathrm{km})\end{array}$ \\
\hline $\mathrm{B}$ & $04 / 06 / 98$ & $42^{\circ} 55^{\prime} 23$ & $0^{\circ} 05^{\circ} 08^{\prime} 33$ & 1200 & 37.0 \\
$\mathrm{C}$ & $04 / 06 / 98$ & $43^{\circ} 04^{\prime} 06$ & $0^{\circ} 07^{\prime} 50$ & 157 & 24.1 \\
$\mathrm{D}$ & $05 / 06 / 98$ & $43^{\circ} 15^{\prime} 05$ & $0^{\circ} 07^{\prime} 95$ & 78 & 9.3 \\
$\mathrm{E}$ & $15 / 06 / 98$ & $42^{\circ} 40^{\prime} 00$ & $04^{\circ} 45^{\prime} 00$ & 1380 & 75.9 \\
$\mathrm{~F}$ & $05 / 06 / 98$ & $42^{\circ} 54^{\prime} 91$ & $04^{\circ} 44^{\prime} 95$ & 240 & 46.3 \\
$\mathrm{G}$ & $05 / 06 / 98$ & $43^{\circ} 04^{\prime} 02$ & $04^{\circ} 44^{\prime} 96$ & 95 & 29.6 \\
$\mathrm{H}$ & $05 / 06 / 98$ & $43^{\circ} 14^{\prime} 97$ & $04^{\circ} 44^{\prime} 96$ & 75 & 11.1 \\
$\mathrm{I}$ & $17 / 06 / 98$ & $42^{\circ} 39^{\prime} 98$ & $04^{\circ} 22^{\prime} 99$ & 830 & 79.6 \\
$\mathrm{~J}$ & $06 / 06 / 98$ & $42^{\circ} 44^{\prime} 97$ & $04^{\circ} 19^{\prime} 04$ & 340 & 72.2 \\
$\mathrm{~K}$ & $06 / 06 / 98$ & $42^{\circ} 59^{\prime} 01$ & $04^{\circ} 14^{\prime} 91$ & 94 & 51.9 \\
$\mathrm{~L}$ & $06 / 06 / 98$ & $43^{\circ} 12^{\prime} 01$ & $04^{\circ} 13^{\prime} 02$ & 87 & 27.8 \\
$\mathrm{~N}$ & $07 / 06 / 98$ & $42^{\circ} 20^{\prime} 01$ & $03^{\circ} 35^{\prime} 01$ & 380 & 22.2 \\
$\mathrm{O}$ & $07 / 06 / 98$ & $42^{\circ} 54^{\prime} 35$ & $03^{\circ} 51^{\prime} 90$ & 92 & 50.0 \\
$\mathrm{P}$ & $07 / 06 / 98$ & $43^{\circ} 07^{\prime} 00$ & $03^{\circ} 48^{\prime} 00$ & 91 & 29.6 \\
$\mathrm{R}$ & $08 / 06 / 98$ & $42^{\circ} 35^{\prime} 07$ & $03^{\circ} 37^{\prime} 03$ & 175 & 37.0 \\
$\mathrm{~S}$ & $08 / 06 / 98$ & $42^{\circ} 48^{\prime} 13$ & $03^{\circ} 28^{\prime} 92$ & 96 & 35.2 \\
$\mathrm{~T}$ & $08 / 06 / 98$ & $43^{\circ} 01^{\prime} 05$ & $03^{\circ} 19^{\prime} 98$ & 66 & 20.4 \\
$\mathrm{U}$ & $16 / 06 / 98$ & $42^{\circ} 27^{\prime} 68$ & $03^{\circ} 29^{\prime} 92$ & 910 & 20.4 \\
$\mathrm{~V}$ & $16 / 06 / 98$ & $42^{\circ} 29^{\prime} 61$ & $03^{\circ} 09^{\prime} 55$ & 35 & 1.9 \\
\hline
\end{tabular}




\begin{tabular}{|c|c|c|c|}
\hline$>$ & 1 & 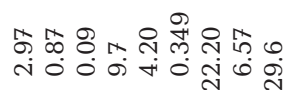 & 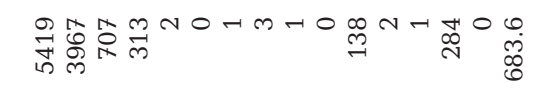 \\
\hline$\supset$ & & 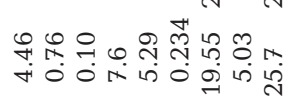 & $00^{4} 0-10$ \\
\hline$\mapsto$ & $\begin{array}{ll}\vec{b} \\
\Leftrightarrow\end{array}$ & 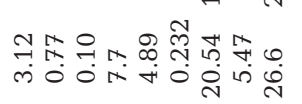 & 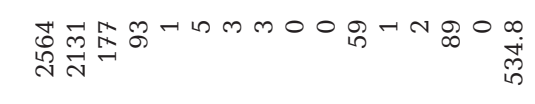 \\
\hline is & 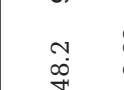 & 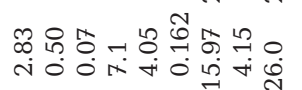 & 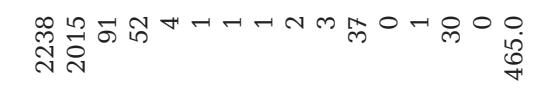 \\
\hline$\simeq$ & & 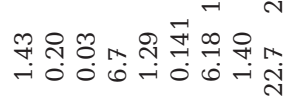 & 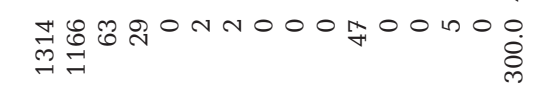 \\
\hline$n_{1}$ & 象 & तुe & $P \operatorname{m}^{\circ} \rightarrow \mathrm{N}$ \\
\hline 0 & & 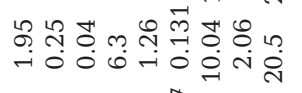 & 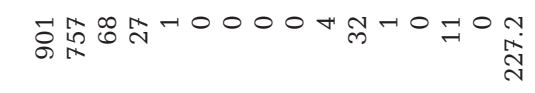 \\
\hline $\mathrm{z}$ & $\underset{\text { I }}{\text { T }}$ & 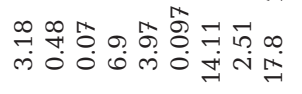 & $n \rightarrow O O N O$ \\
\hline 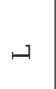 & & 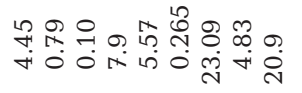 & $m^{\circ} \circ N^{N}$ \\
\hline 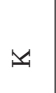 & $\stackrel{\infty}{\ddot{n}}$ & 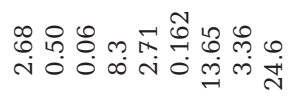 & 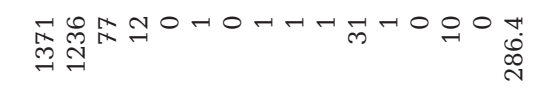 \\
\hline$\neg$ & $\underset{m}{m}$ & 认̂t & 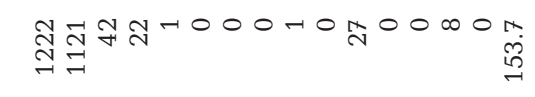 \\
\hline$\neg$ & $\begin{array}{l}0 \\
\infty \\
\infty\end{array}$ & 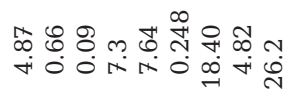 & toOONO \\
\hline 出 & $\begin{array}{l}-1 \\
\infty \\
\infty\end{array}$ & 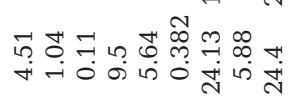 & $p \rightarrow 4-\infty$ \\
\hline U & $\underset{\infty}{\infty}$ & 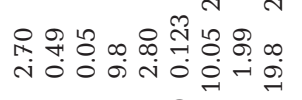 & ONOO \\
\hline 山 & & 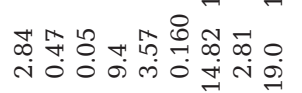 & Om mono \\
\hline 피 & $\stackrel{\#}{\infty}$ & 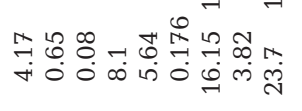 & $\begin{aligned} r \infty & 0\end{aligned}$ - \\
\hline D & $\vec{\infty}$ & 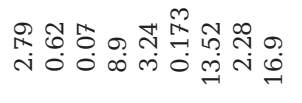 & $\mathrm{ON}$ \\
\hline$U$ & $\underset{\mathbb{N}}{\mathbb{N}}$ & 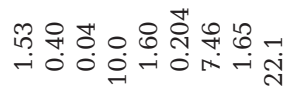 & 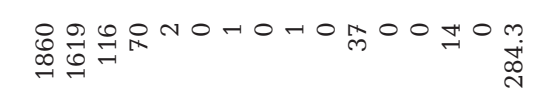 \\
\hline$\infty$ & ํ. & 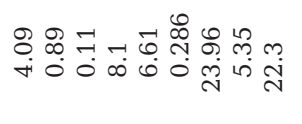 & $b-r \bar{c}$ \\
\hline 急 & $\begin{array}{l}\overrightarrow{0} \\
\dot{3} \\
0\end{array}$ & 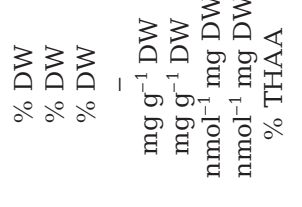 & 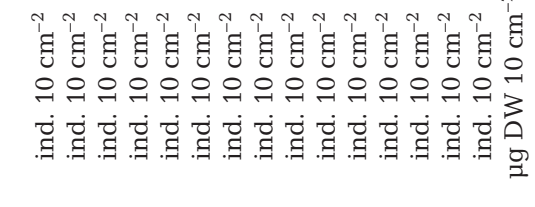 \\
\hline 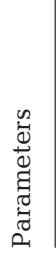 & 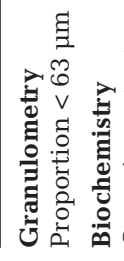 & 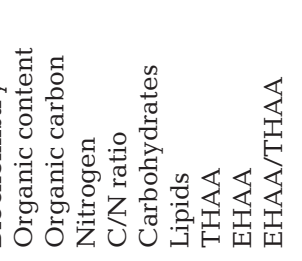 & 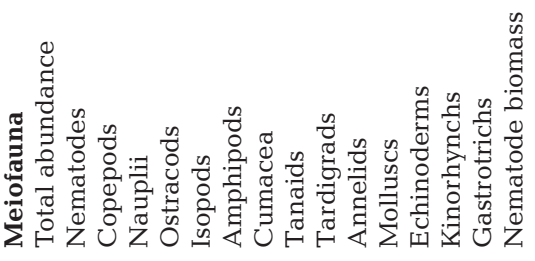 \\
\hline
\end{tabular}

possible degradation of the enzyme was carried out.

We decided to use spectrofluoremetrical instead of HPLC measurements because of the results of previous surveys showing that THAA and EHAA amino acid mole distributions within both sedimenting (Medernach et al. 2001) and sedimented POM (Medernach 2000) collected in different seasons and in various parts of the Gulf of Lions are almost constant.

Sediment granulometry. At each site, sediment granulometry was assessed (triplicates) within the same cores and on the same fraction used for the biochemical assays using a Malvern ${ }^{\circledR}$ Mastersizer 2000 laser microgranulometer.

Meiofauna. At each site, 3 other cores were randomly selected from the 2 multi-corer drops. They were subsampled for meiofauna to a depth of $5 \mathrm{~cm}$ using a $6.16 \mathrm{~cm}^{2}$ syringe that was vertically inserted into the sediment. The collected sediment was fixed with $4 \%$ formalin in buffered seawater. Back at the laboratory, meiofauna was sieved on a $40 \mu \mathrm{m}$ mesh. The fraction retained on this mesh was diluted in ludox HS-40 containing kaolin and centrifuged (5500 rpm, $15 \mathrm{~min}$ ). The supernatant was passed through a $40 \mu \mathrm{m}$ mesh, and the fraction retained on this mesh was collected and fixed with formalin. These operations were repeated 3 times, leading to an extraction efficiency of $94 \%$ (Keller 1984, 1985). Meiofauna was identified to the main taxa and counted under a stereo dissecting microscope. Nematode biomass was determined using the biometric approach proposed by deBovée (1987).

Data analysis. Relationships between both biochemical and faunal parameters and either depth or distance to the coast were assessed using semi-logarithmic and simple linear regression models, respectively.

Because of the existence of different patterns of changes in both granulometrical/biochemical and faunal parameters relative to depth, we decided to focus on the 0 to $175 \mathrm{~m}$ depth range to 
assess the interactions between biochemical and faunal parameters. This was achieved through a principal component analysis (PCA) based on depth, distance to the coast, biochemical parameters (organic content, organic carbon, nitrogen, carbohydrates, lipids, THAA, EHAA, EHAA/THAA ratio), meiofauna abundance and nematode biomass. These relationships were also assessed using simple linear regression models.

\section{RESULTS}

\section{Sediment granulometry}

The percentages of particles $<63 \mu \mathrm{m}$ in diameter were between 12.5\% (Stn O) and 98.2\% (Stn L; Table 2, Fig. 2). They tended to be lower at the stations located at intermediate depths near the shelf break (Stns J, K, O, R and S). Proportions of the silt-clay fraction tended also to be low at Stns G and C, but to a lesser extent, possibly due to the proximity of the Rhône River.

\section{Biochemistry}

The main characteristics of sedimentary organics at the sampled stations are presented in Table 2. Organic contents were between $1.43 \%$ (Stn R) and $4.87 \%$ (Stn I). Organic carbon concentrations were between $0.20 \%$ (Stn R) and $1.04 \%$ (Stn H). Nitrogen concentrations were between $0.03 \%$ (Stn R) and $0.11 \%$ (Stns B and $\mathrm{H}$ ). $\mathrm{C} / \mathrm{N}$ ratios were between 6.3 (Stn O) and 10.0 (Stn C). Carbohydrate concentrations were between 1.26 (Stn O) and $7.64 \mathrm{mg} \mathrm{g}^{-1} \mathrm{DW}$ (Stn I). Lipid concentrations were between 0.097 (Stn N) and $0.382 \mathrm{mg} \mathrm{g}^{-1}$ DW (Stn H). THAA were between 6.18 (Stn R) and

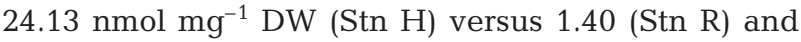

Table 3. Main characteristics of the linear regression models linking the proportion of particles $<63 \mu \mathrm{m}$ in diameter and biochemical parameters. Significant correlations $(p<0.05)$ are in bold $\left(r^{2}\right.$, determination coefficient; $\mathrm{p}$, probability)

\begin{tabular}{|lccrr|}
\hline Dependent variables & $\mathrm{r}^{2}$ & $\mathrm{p}$ & Slope & Intercept \\
\hline Organic contents & $\mathbf{0 . 4 8 9}$ & $\mathbf{0 . 0 0 4}$ & $\mathbf{1 8 . 4 2 2}$ & $\mathbf{1 3 . 1 3 4}$ \\
Organic carbon & $\mathbf{0 . 6 7 2}$ & $\mathbf{0 . 0 0 1}$ & $\mathbf{1 0 7 . 0 3 8}$ & $\mathbf{9 . 9 9 5}$ \\
Nitrogen & $\mathbf{0 . 5 9 0}$ & $\mathbf{0 . 0 0 1}$ & $\mathbf{8 7 5 . 8 0 2}$ & $\mathbf{8 . 8 5 7}$ \\
Lipids & $\mathbf{0 . 3 1 7}$ & $\mathbf{0 . 0 2 9}$ & $\mathbf{2 2 1 . 2 8 4}$ & $\mathbf{2 7 . 6 3 9}$ \\
Carbohydrates & $\mathbf{0 . 4 6 5}$ & $\mathbf{0 . 0 0 5}$ & $\mathbf{1 0 . 4 1 6}$ & $\mathbf{2 9 . 2 0 8}$ \\
THAA & $\mathbf{0 . 4 2 5}$ & $\mathbf{0 . 0 0 8}$ & $\mathbf{2 6 . 5 4 0}$ & $\mathbf{1 8 . 8 7 9}$ \\
EHAA & $\mathbf{0 . 3 0 3}$ & $\mathbf{0 . 0 3 4}$ & $\mathbf{8 0 . 8 6 1}$ & $\mathbf{3 3 . 5 5 8}$ \\
EHAA/THAA ratio & 0.000 & 0.992 & 0.025 & 69.006 \\
C/N ratio & 0.193 & 0.101 & 10.393 & -13.713 \\
\hline
\end{tabular}

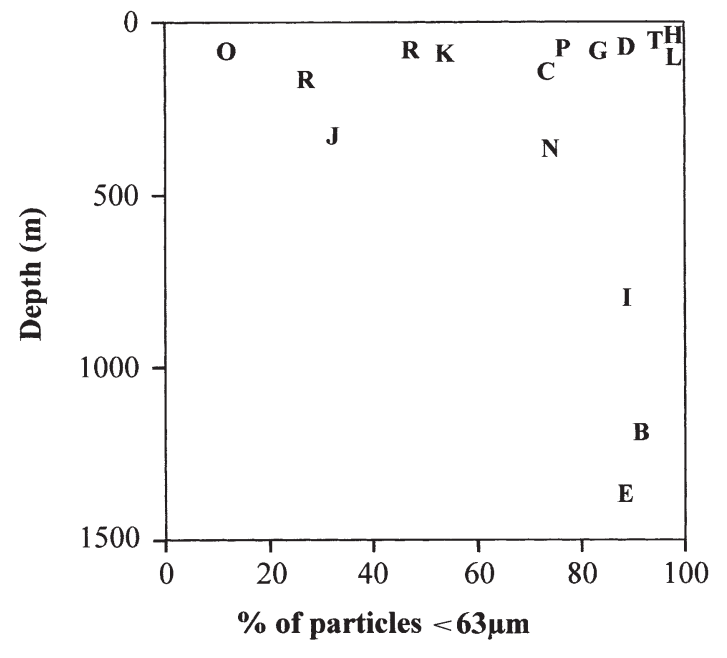

Fig. 2. Relationship between the proportion of particles $<63 \mu \mathrm{m}$ in diameter and water depth

$6.57 \mathrm{nmol} \mathrm{mg}^{-1} \mathrm{DW}$ (Stn V) for EHAA. EHAA/THAA ratios were between $16.9 \%$ (Stn D) and $29.6 \%$ (Stn V).

For all biochemical parameters, concentrations featured the same pattern of change relative to depth. A decrease was found between 0 and $175 \mathrm{~m}$, followed by an increase between 175 and $900 \mathrm{~m}$ and then a further decrease at greater depths. This was apparently due to change in granulometry since all biochemical parameters but C/N and EHAA/THAA ratios correlated positively with the proportion of particles $<63 \mu \mathrm{m}$ in size $(p<0.034$ in all cases, Table 3$)$. None of the biochemical parameters correlated significantly with the distance to the coast ( $p>0.119$ in all cases, data not shown).

\section{Meiofauna}

Total abundances of meiofauna were between 530 (Stn E) and 5419 ind. $10 \mathrm{~cm}^{-2}$ (Stn V) (cf. Table 2). Abundances measured at Stns $\mathrm{H}$ and V were clearly the highest ones. For the other stations there was a continuous trend of decreasing abundance with increasing depth (Fig. 3A). The best fit between these 2 parameters was obtained using a semi-logarithmic regression model $\left(\mathrm{N}=19, \mathrm{r}^{2}=0.453, \mathrm{p}=0.002\right)$. Meiofauna abundance also correlated negatively with the distance to the coast $\left(\mathrm{N}=19, \mathrm{r}^{2}=0.432, \mathrm{p}=0.002 \mathrm{using}\right.$ a simple linear regression model).

Nematodes were always dominant (i.e. accounting for between 73 and $97 \%$ of total meiofauna abundance). Their biomass ranged between 99.0 (Stn E) and $722.3 \mu \mathrm{g} \mathrm{DW} 10 \mathrm{~cm}^{-2}$ (Stn H) (Table 2). They correlated negatively with depth $\left(\mathrm{N}=19, \mathrm{r}^{2}=0.608, \mathrm{p}<0.001\right.$ using a semi-logarithmic model; Fig. 3B) and with the distance to the coast $\left(\mathrm{N}=19, \mathrm{r}^{2}=0.487, \mathrm{p}<0.001\right)$. 

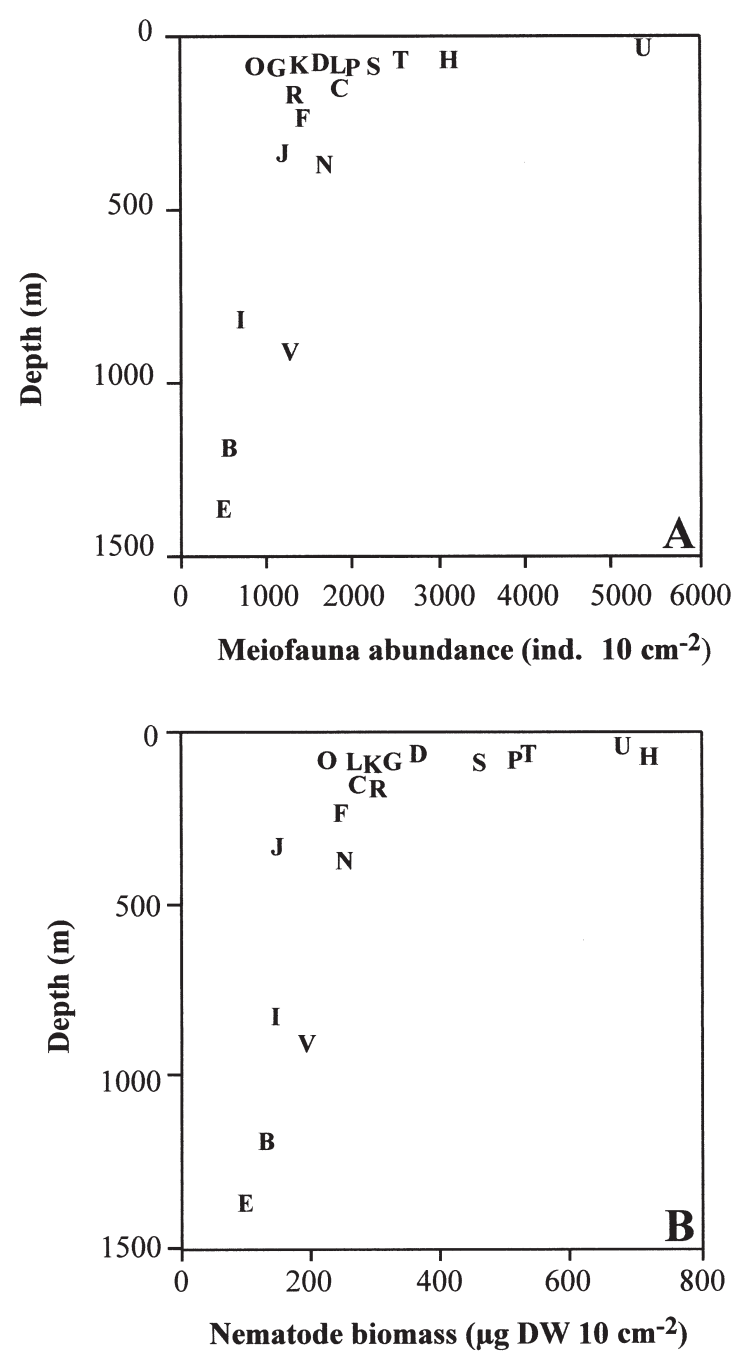

Fig. 3. Relationships between total (A) meiofauna abundance and (B) nematode biomass and water depth

\section{Relationships between parameters}

Projections of variables on the first plane of the PCA involving biochemical parameters, meiofauna abundance and nematode biomass in the 0 to $175 \mathrm{~m}$ depth range are presented in Fig. 4. The first component accounted for $73.4 \%$ of total variance and the second one for $10.8 \%$. Component 1 was characterized by the opposition between depth and distance to the coast on one side and all biochemical parameters on the other side. It was interpreted as reflecting quantitative changes in sedimentary organics. Component 2 allowed separation of biochemical parameters, with a gradient from lipids and EHAA to organic contents and carbohydrates. It was interpreted as indicative of changes in the lability of sedimentary organics. Both meiofauna abundance and nematode biomass were associated with biochemical parameters and most tightly with lipids and EHAA. These results were supported by simple regression analysis. When considering all stations with depth of $<175 \mathrm{~m}$, meiofauna abundances indeed correlated positively with organic carbon, nitrogen, lipids, THAA and EHAA, but not with total organic contents and carbohydrates (Table 4). The best fits were obtained using lipids and EHAA. The same pattern was true for nematode biomass, except that this parameter also correlated positively with carbohydrates.

\section{DISCUSSION}

\section{Comparison with literature data}

Comparison of our results regarding sedimentary organics with literature data is based on available data regarding either the Gulf of Lions ( $C$ and $N$ ), other parts of the Mediterranean (carbohydrates and lipids), or even other parts of Europe (EHAA, THAA, EHAA/ THAA ratio). The ranges of organic carbon and nitrogen concentrations recorded during the present study are in good agreement with those (i.e. between 0.27 and $0.78 \%$ DW and 0.03 and $0.11 \%$ DW, respectively) reported by deBovée et al. (1990) and then Buscail \& Germain (1997) within the Gulf of Lions. Moreover, the standardization for depth leads to almost equivalent concentrations. When standardized for depth, carbo-

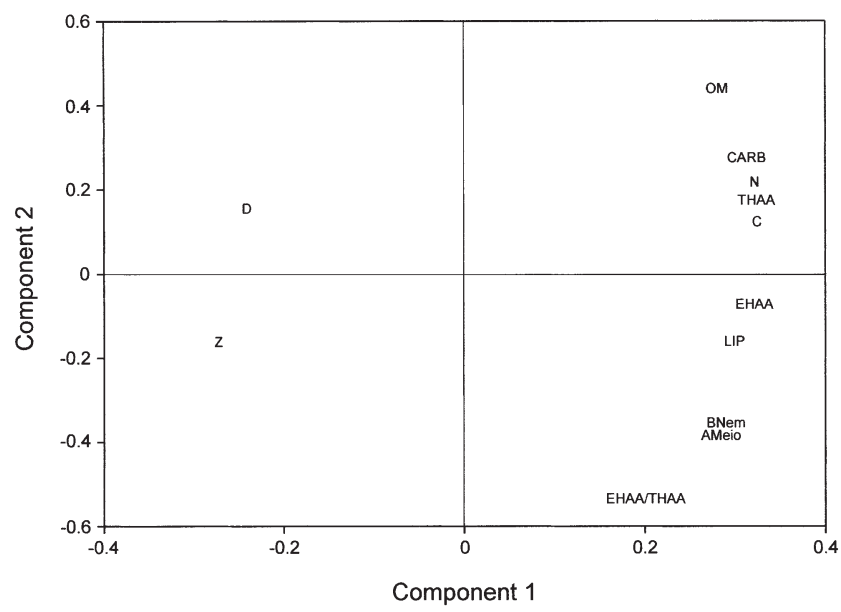

Fig. 4. Projections of variables on the first plane of principal component analysis based on biochemical parameters, meiofauna abundance and nematode biomass at the stations located within the 0 to $175 \mathrm{~m}$ depth range $(Z$, depth; $D$, distance to the coast; $\mathrm{C}$, organic carbon; $\mathrm{N}$, nitrogen; OM, organic contents; CARB, carbohydrates; LIP, lipids; THAA, total hydrolyzable amino acids; EHAA, enzymatically hydrolyzable amino acids; EHAA/THAA, enzymatically to total hydrolyzable amino acid ratios; AMeio, abundance of meiofauna; BNem, biomass of nematodes) 
hydrate and lipid concentrations measured during the present study are slightly higher than those recorded either in the Gulf of Marconi (Albertelli et al. 1999) or along a transect between the Aegean and the Ionian Seas (Danovaro et al. 1993). Such differences may reflect more intense oligotrophy in these parts of the Mediterranean than in the Gulf of Lions, where continental inputs associated with the Rhône River are important (Pont 1997).

Assuming an average molecular weight of $132 \mathrm{~g}$, our THAA concentrations are between 0.819 and $3.200 \mathrm{mg} \mathrm{g}^{-1} \mathrm{DW}$. This is slightly higher than the protein concentrations (between 0.900 and $1.400 \mathrm{mg} \mathrm{g}^{-1}$ DW) recently reported for the Porcupine abyssal plain (Dell'Anno et al. 2000), but in the range of existing data regarding coastal sediments (i.e. $<7.6 \mathrm{mg} \mathrm{g}^{-1}$ DW according to Dauwe et al. 1999). EHAA concentrations are between 0.185 and $0.871 \mathrm{mg} \mathrm{g}^{-1}$ DW. Here again, this is slightly higher than the values reported for the Porcupine abyssal plain (i.e. between 0.020 and $0.320 \mathrm{mg} \mathrm{g}^{-1} \mathrm{DW}$ according to Dell'Anno et al. 2000), but in good agreement with existing data regarding coastal sediments (i.e. between 0.130 and $2.200 \mathrm{mg} \mathrm{g}^{-1} \mathrm{DW}, 1.8 \mathrm{mg} \mathrm{g}^{-1}$ DW and $<1 \mathrm{mg} \mathrm{g}^{-1}$ DW according to Mayer et al. 1986, 1995 and Dauwe et al. 1999, respectively). EHAA/THAA ratios are between 16.9 and $29.6 \%$, which is in good agreement with the intermediate values reported by Dauwe et al. (1999) along a production/degradation gradient in the North Sea. Such values appear to be indicative of areas where degradation processes are dominant.

Meiofauna abundances are also in good agreement with literature data regarding the Mediterranean (deBovée et al. 1990, Medernach 2000).

\section{Changes of sedimentary organics relative to depth}

The spatial distribution of sedimentary organic biochemical characteristics within the Gulf of Lions has been previously assessed based on samples collected between 1983 and 1987 at depths ranging between 600 and $2300 \mathrm{~m}$ (deBovée et al. 1990, Buscail \& Germain 1997). Those samples were mostly collected within submarine canyons of both the Rhodanian and the Catalan margins (i.e. the center of the Gulf of Lions was not sampled). Results suggested: (1) a significant increase of sedimentary organic carbon concentrations within canyons, (2) the impact of both the position of the canyons relative to the Liguro-Provençal current and the width of the adjacent shelf on organic carbon concentrations, (3) higher organic carbon concentration in the upper than in the lower axis of submarine canyons, and (4) no significant changes in organic carbon concentration with depth on the open slope. Bio-
Table 4. Main characteristics of the linear regression models linking biochemical parameters and fauna characteristics in the 0 to $175 \mathrm{~m}$ depth range. Significant correlations $(p<0.05)$ are in bold $\left(\mathrm{r}^{2}\right.$, determination coefficient; $\mathrm{p}$, probability)

\begin{tabular}{|c|c|c|}
\hline $\begin{array}{l}\text { Independent variables } \\
\text { Regression parameters }\end{array}$ & $\begin{array}{l}\text { Meiofauna } \\
\text { abundance }\end{array}$ & $\begin{array}{c}\text { Nematode } \\
\text { biomass }\end{array}$ \\
\hline \multicolumn{3}{|l|}{ Organic contents } \\
\hline $\mathrm{r}^{2}$ & 0.121 & 0.278 \\
\hline $\mathrm{p}$ & 0.268 & 0.078 \\
\hline Slope & 437.9 & 46.6 \\
\hline Intercept & 865.1 & 79.3 \\
\hline \multicolumn{3}{|l|}{ Organic carbon } \\
\hline $\mathrm{r}^{2}$ & 0.482 & 0.593 \\
\hline $\mathrm{p}$ & 0.012 & 0.003 \\
\hline Slope & 3365.7 & 262.2 \\
\hline Intercept & 152.0 & 59.4 \\
\hline \multicolumn{3}{|l|}{ Nitrogen } \\
\hline $\mathrm{r}^{2}$ & 0.353 & 0.521 \\
\hline $\mathrm{p}$ & 0.042 & 0.008 \\
\hline Slope & 27011.5 & 2301.7 \\
\hline Intercept & 222.0 & 51.0 \\
\hline \multicolumn{3}{|l|}{ Lipids } \\
\hline$r^{2}$ & 0.661 & 0.605 \\
\hline $\mathrm{p}$ & 0.001 & 0.003 \\
\hline Slope & 11728.7 & 787.9 \\
\hline Intercept & -343.3 & 47.2 \\
\hline \multicolumn{3}{|l|}{ Carbohydrates } \\
\hline$r^{2}$ & 0.263 & 0.452 \\
\hline $\mathrm{p}$ & 0.088 & 0.016 \\
\hline Slope & 397.1 & 36.5 \\
\hline Intercept & 737.5 & 85.7 \\
\hline \multicolumn{3}{|l|}{ THAA } \\
\hline$r^{2}$ & 0.423 & 0.516 \\
\hline $\mathrm{p}$ & 0.022 & 0.008 \\
\hline Slope & 986.9 & 76.5 \\
\hline Intercept & 166.6 & 61.4 \\
\hline \multicolumn{3}{|l|}{ EHAA } \\
\hline$r^{2}$ & 0.612 & 0.676 \\
\hline $\mathrm{p}$ & 0.003 & 0.001 \\
\hline Slope & 4068.8 & 300.3 \\
\hline Intercept & 178.0 & 69.3 \\
\hline \multicolumn{3}{|l|}{$\mathrm{C} / \mathrm{N}$} \\
\hline$r^{2}$ & 0.170 & 0.087 \\
\hline $\mathrm{p}$ & 0.182 & 0.351 \\
\hline Slope & 380.0 & 19.1 \\
\hline Intercept & -1015.1 & 55.0 \\
\hline \multicolumn{3}{|l|}{ EHAA/THAA } \\
\hline$r^{2}$ & 0.475 & 0.452 \\
\hline $\mathrm{p}$ & 0.013 & 0.017 \\
\hline Slope & 228.6 & 15.6 \\
\hline Intercept & -3250.4 & -154.6 \\
\hline
\end{tabular}

chemical descriptors aiming at assessing the bioavailable fraction of sedimentary organics were not assayed during this survey.

Our own results suggest the existence of a single pattern of change in sedimentary organics relative to depth for the Gulf of Lions. They show that sedimentary organic concentration decreases with depth on the 
continental shelf. This diminution matches changes in mean annual carbon organic fluxes recorded in the Grand Rhône canyon (Monaco et al. 1999). Sedimentary organic concentrations then clearly increase with depth between 175 and 900 m (upper slope). Based on the analysis of the regression linking gross sedimentation rates and concentrations of sedimenting POM in various biochemical components, Medernach (2000) compared the ability of these components to account for the lability of POM. She showed that lipids and EHAA were both associated with the most labile fraction, whereas carbohydrates were associated with the most refractory one. The fact that the increase of sedimentary organic concentration on the upper slope was recorded for all biochemical components (and more or less in the same proportions irrespective of their association with a more or less labile POM fraction) suggests that this augmentation does not result from the accumulation of degraded POM. Preferential deposition on the upper slope has been directly documented in the Grand Rhône canyon, where Monaco et al. (1999) reported a maximum of annual organic carbon flux at $600 \mathrm{~m}$. Unfortunately, there are only few available data regarding near-bottom vertical fluxes in the Gulf of Lions. Those compiled by Durrieu de Madron et al. (2000), however, suggest a constant decrease with depth. Moreover, the negative relationship between sediment grain size and concentration of sedimentary organics also pinpoints the effect of sediment granulometry. Higher organic contents are well known to be associated with finer sediments, both through an increase of surface/volume ratios (Mayer 1994). During the present survey, the low concentrations of sedimentary organics recorded near the shelf break were indeed clearly associated with coarser sediments within littoral relict formations. More generally, the presence of coarse sediment at the shelf break constitutes one of the characteristics of continental margins when submitted to strong currents such as the LiguroProvençal current (Blake \& Doyle 1983). Hydrodynamics could thus act both in limiting sedimentation and in controlling sediment granulometry at the shelf break of the Gulf of Lions continental margin.

\section{Relationships between sedimentary organics and benthic meiofauna}

The relationship between sedimentary organics and benthic meiofauna in the Gulf of Lions has been previously assessed by deBovée et al. (1990) based on 2 cruises carried out during summer and autumn 1986 at depths ranging from 672 to $2367 \mathrm{~m}$. These authors reported a constant decrease of sedimentary organic concentrations and meiofauna abundance with depth.
This result was interpreted as reflecting the distance from the food source. The analysis of vertical changes in particulate fluxes in the Gulf of Lions, however, suggests that this pattern probably does not hold for the whole margin (Monaco et al. 1999). Moreover, because of the nature of the biochemical parameters (i.e. organic carbon, nitrogen and chlorophyllous pigments) that were assayed by deBovée et al. (1990), it was difficult to attribute the lack of fit of the regression models linking the biochemical characteristics of sedimentary organics and the quantitative characteristics of benthic fauna either to a real lack of functional relationship or to the absence of consideration of the changes in sedimentary POM nutritional value.

During the present study, a much wider depth range was sampled, and meiofauna quantitative characteristics still showed a constant decrease with depth. In the Mediterranean, sediment granulometry does not seem to significantly affect the abundance of meiofauna (deBovée et al. 1990). Changes in quantitative characteristics of benthic fauna with depth are often attributed to organic matter, oxygen availability, and/or the interaction between these 2 parameters (Levin et al. 2000). Because of strong mixing during winter and oligotrophy, Mediterranean waters are almost always well oxygenated (Minas \& Bonin 1988), explaining why the decrease of Mediterranean benthic meiofauna with depth has been previously attributed to a decrease in food availability (deBovée et al. 1990, see above).

During the present study, there was a positive correlation between sedimentary organics and both meiofauna abundance and nematode biomass on the continental shelf. Data from this zone were thus used to compare the validity of several biochemical parameters for describing quantitative changes in benthic fauna. This comparison shows the existence of a tight relationship between meiofauna (abundance and biomass) and lipids and EHAA. Based on the results of the regression models between sedimentary organic and meiofauna characteristics, it can be estimated that the use of EHAA instead of $\mathrm{N}$ results in an increase of about $20 \%$ in the proportion of quantitative changes in the meiofauna explained by organic matter availability. In this sense, our data thus tend to support the use of the biomimetic approach proposed by Mayer et al. $(1986,1995)$ for assessing the bioavailable fraction of sedimentary organics. This result is in good agreement with both: (1) the initial calibration of the biomimetic approach using Parastichopus californicus gut fluid (Mayer et al. 1995) and (2) the positive correlation found between available protein rations and growth in the bivalve Abra ovata (Grémare et al. 1997). Food quality is not an inherent property of the sediment itself but rather results from an interaction between 
sediment and benthic organisms (Mayer et al. 1995). Because digestive capacities differ among benthic invertebrates, generalized validation of the biomimetic approach based on single benthic species remains equivocal (Mayer et al. 1995). Results of the present study are thus important because they tend to support this approach based on data regarding the whole meiofauna community. Our results also pinpoint the inadequacy of the labile organic matter concept, which has been extensively used in the Mediterranean (Danovaro et al. 1993, 1995), as an indicator of POM nutritional value. Total proteins, carbohydrates and lipids are indeed associated with different levels of: (1) organic matter lability (Medernach 2000) and (2) correlation with quantitative characteristics of benthic fauna (Medernach 2000, present study). Part of the lack of fit of regression models linking total carbohydrates and quantitative characteristics of meiofauna may result from the existence of both digestible and refractory forms of carbohydrates. This is also true, although to a lesser extent, for the lipid fraction, which includes a variety of structures. Biomimetic approaches regarding the bioavailability of these 2 kinds of compounds (such as recently proposed by Dell'Anno et al. 2000) will thus certainly prove very suitable in the near future.

There was no positive correlation between sedimentary organic concentrations and either meiofauna abundance or nematode biomass on the upper slope. This pattern was observed for all the biochemical parameters assessed during the present survey, including lipids and EHAA, which are presently thought to be associated with the labile organic matter that can indeed be used by the benthic fauna (Grémare et al. 1997, Medernach 2000, present study). Thus, it seems very unlikely that organic matter availability controls the abundance and the biomass of benthic meiofauna on the upper slope of the Gulf of Lions. At this stage hypotheses relative to the factor(s) controlling benthic communities in this zone are still largely speculative. It can only be underlined that both the steepness of the upper slope and its relatively shallow depth contribute to increase its instability, which could affect the establishment of dense benthic populations.

\section{CONCLUSIONS}

In conclusion, our data clearly show that both lipids and EHAA, which are associated with the most labile fraction of sedimentary organics, correlate better with quantitative changes in benthic meiofauna than THAA, C, N, carbohydrates or total organic contents. Discrepancies in the pattern of changes of both sedi- mentary organic biochemical characteristics and benthic meiofauna with depth also suggest that organic matter availability is not controlling the meiofauna standing stock on the upper slope of the Gulf of Lions. Further studies are required to unravel the ecological factors controlling benthic fauna abundance in this particular depth range.

Acknowledgements. This research was funded through the French National Program on Coastal Environment (PNEC, Chantier Golfe du Lion). L. M. was supported by a predoctoral fellowship of the French Ministère de la Recherche et de la Technologie. Thanks are due to Jean-François Verleene and Christophe Bertrand for their help with the processing of some of the samples. We would also like to thank X. Durrieu de Madron and A. Dinet for their comments on an earlier draft of this manuscript.

\section{LITERATURE CITED}

Albertelli G, Covazzi-Harriague A, Danovaro R, Fabiano M, Fraschetti S, Pusceddu A (1999) Differential responses of bacteria, meiofauna and macrofauna in a shelf area (Ligurian Sea, NW Mediterranean): role of food availability. J Sea Res 42:11-26

Barnes H, Blackstock J (1973) Estimation of lipids in marine animals and tissues: detailed investigation of the sulphophosphovanillin method for 'total' lipids. J Exp Mar Biol Ecol 12:103-118

Bishop JDD, Shalla SH (1994) Discrete seasonal reproduction in an abyssal peracarid crustacean. Deep-Sea Res I 41: 1798-1800

Blake NJ, Doyle LJ (1983) Infaunal-sediment relationships at the shelf-slope break. SEPM Spec Publ 33:381-389

Buscail R, Germain C (1997) Present-day organic matter sedimentation on the NW Mediterranean margin: importance of shelf export. Limnol Oceanogr 42:217-229

Charles F, Amouroux JM, Grémare A, Baudart J (1995) A bioassay approach to seasonal variation in the nutritional value of sediment trap material. J Exp Mar Biol Ecol 191: $65-81$

Danovaro R, Fabiano M, Della Croce N (1993) Labile organic matter and microbial biomasses in deep-sea sediments (eastern Mediterranean Sea). Deep-Sea Res 40:953-965

Danovaro R, Fabiano M, Albertelli G, Della Croce N (1995) Vertical distribution of meiobenthos in bathyal sediments of the eastern Mediterranean Sea: relationship with labile organic matter and bacterial biomasses. PSZN I: Mar Ecol 16:103-116

Dauwe B, Middelburg JJ, Van Rijswijk P, Sinke J, Herman PMJ, Heip CHR (1999) Enzymatically hydrolyzable amino acids in North Sea sediments and their possible implication for sediment nutritional values. J Mar Res 57:109-134

deBovée F (1987) Biomasse et équivalents énergétiques des nématodes libres marins. Cah Biol Mar 28:367-372

deBovée F, Guidi LD, Soyer J (1990) Quantitative distribution of deep-sea meiobenthos in the northwestern Mediterranean (Gulf of Lions). Cont Shelf Res 10:1123-1145

Dell'Anno A, Fabiano M, Mei ML, Danovaro R (2000) Enzymatically hydrolysed protein and carbohydrate pools in deep-sea sediments: estimates of the potentially bioavailable fraction and methodological considerations. Mar Ecol Prog Ser 196:15-23 
Dubois M, Gilles KA, Hamilton JK, Rebers PA, Smith F (1956) Colorimetric method for determination of sugars and related substances. Anal Chem 28:350-356

Durrieu de Madron X, Abassi A, Heussner S, Monaco A and 5 others (2000) Particulate matter and organic carbon budgets for the Gulf of Lions (NW Mediterranean). Oceanol Acta 23:717-731

Flach E, Vanaverbeke J, Heip C (1999) The meiofauna: macrofauna ratio across the continental slope of the Goban Spur (north-east Atlantic). J Mar Biol Assoc UK 79: $233-241$

Graf G (1992) Benthic-pelagic coupling: a benthic view. Oceanogr Mar Biol Annu Rev 30:149-190

Graf G, Schulz P, Peinert P, Meyer-Reil A (1983) Benthic response to sedimentation events during autumn to spring at a shallow water station in the western Kiel Bight. I. Analysis of processes on a community level. Mar Biol 77: 235-246

Grémare A, Amouroux JM, Charles F, Dinet A and 7 others (1997) Temporal changes in the biochemical composition and nutritional value of the particulate organic matter available to surface deposit-feeders: a two year study. Mar Ecol Prog Ser 150:195-206

Hargrave BT (1973) Coupling carbon flow through some pelagic and benthic communities. J Fish Res Board Can 30:1317-1326

Hecker B (1990) Photographic evidence for the rapid flux of particles to the sea floor and their transport down the continental slope. Deep-Sea Res 37:1773-1782

Keller M (1984) Influence du rejet en mer de l'égout de Marseille sur les peuplements du meiobenthos. Thèse 3ème cycle, Université de Marseille, Marseille

Keller M (1985) Distribution quantitative de la méiofaune dans l'aire d'épandage de l'égout de Marseille. Mar Biol 89:293-302

Lan CC, Pan BS (1993) In vitro digestibility simulating the proteolysis of feed protein in the midgut gland of grass shrimp Penaeus monodon. Aquaculture 109:59-70

Levin LA, Gage JD, Martin C, Lamont PA (2000) Macrobenthic community structure within and beneath the oxygen minimum zone, NW Arabian Sea. Deep-Sea Res II 47: 189-226

Marsh AG, Tenore KR (1990) The role of nutrition in regulating the population dynamics of opportunistic surface deposit-feeders in a mesohalyne community. Limnol Oceanogr 35:710-724

Mayer LM (1994) Surface area control of organic carbon accumulation in continental shelf sediments. Geochim Cosmochim Acta 58:1271-1284

Mayer LM, Schick LL, Setchell FW (1986) Measurement of protein in nearshore marine sediments. Mar Ecol Prog Ser 30:159-165

Mayer LM, Schick LL, Sawyer T, Plante CJ, Jumars PA, Self RFL (1995) Bioavailable amino acids in sediments: a biomimetic, kinetics-based approach. Limnol Oceanogr 40: 511-520

Medernach L (2000) Relations entre la matière organique et

Editorial responsibility: Kenneth Tenore (Contributing

Editor), Solomons, Maryland, USA la faune benthique dans le golfe du Lion: association de plusieurs approches à différentes échelles de temps et d'espace. PhD thesis, Université Pierre et Marie Curie, Banyuls-sur-Mer

Medernach L, Grémare A, Amouroux JM, Colomines C, Vétion G (2001) Temporal changes in the amino acid contents of particulate organic matter sedimenting in the Bay of Banyuls-sur-Mer (northwestern Mediterranean). Mar Ecol Prog Ser 214:55-65

Minas HJ, Bonin MC (1988) Oxygénation physique et biologique de la Méditerranée nord-occidentale en hiver et au printemps. In: Minas HJ, Nival P (eds) Océanographie pélagique Méditerranéenne: aspects interdisciplinaires de l'océanographie Méditerranéenne dans le domaine pélagique. Oceanol Acta 9(Suppl):123-132

Monaco A, Durrieu de Madron X, Radacovitch O, Heussner S, Carbonne J (1999) Origin and variability of downward biogeochemical fluxes on the Rhône continental margin (NW Mediterranean). Deep-Sea Res 46:1483-1511

Phillips NW (1984) Roles of different microbes and substrates as potential suppliers of specific essential nutrients to marine detritivores. Bull Mar Sci 12:33-47

Plante CJ, Jumars PA (1992) The microbial environment of marine deposit-feeder guts characterized via microelectrodes. Microb Ecol 23:257-277

Plante CJ, Shriver AG (1998) Differential lysis of sedimentary bacteria by Arenicola marina L.: examination of cell wall structure and exopolymeric capsules as correlates. J Exp Mar Biol Ecol 229:35-52

Pont D (1997) Les débits solides du Rhône à proximité de son embouchure: données récentes (1994-1995). Rev Géogr (de Lyon) 72:23-33

Relexans JC, Deming J, Dinet A, Gaillard JF, Sibuet M (1996) Sedimentary organic matter and micro-meiobenthos with relation to trophic conditions in the tropical northeast Atlantic. Deep-Sea Res 8:1343-1368

Smith CR, Hoover DJ, Doan SE, Pope R and 3 others (1996) Phytodetritus at the abyssal seafloor across $10^{\circ}$ of latitude in the central equatorial Pacific. Deep-Sea Res II 43: $1309-1338$

Smith CR, Berelson W, DeMaster D, Dobbs FC and 4 others (1997) Latitudinal variations in benthic processes in the abyssal equatorial Pacific: control by biogenic particle flux. Deep-Sea Res II 9/10:2295-2317

Soltwedel T, Thiel H (1995) Biogenic sediment compounds in relation to marine meiofaunal abundances. Int Rev Gesamt Hydrobiol 80:297-311

Taghon GL, Greene RR (1990) Effects of sediment-protein concentration on feeding and growth rates of Abarenicola pacifica Healy et Wells (Polychaeta: Arenicolidae). J Exp Mar Biol Ecol 136:197-216

Tyler PA, Campos-Creasy LA, Giles LA (1994) Environmental control of quasi-continuous and seasonal reproduction in deep-sea benthic invertebrates. In: Young CM, Eckelbarger KJ (eds) Reproduction, larval biology and recruitment of the deep-sea benthos. Columbia University Press, New York, p 158-178

Submitted: March 25, 2001; Accepted: November 15, 2001 Proofs received from author(s): April 26, 2002 